\title{
Penggunaan Metode Inkuiri pada Mata Kuliah Statistik Ekonomi dalam Meningkatkan Hasil Belajar Mahasiswa Prodi Manajemen Fakultas Ekonomi Universitas Samudra
}

\author{
Suri Amilia \\ Fakultas Ekonomi, Universitas Samudra \\ e-mail: suri.amilia@unsam.ac.id
}

\begin{abstract}
Abstrak
Metode pembelajaran adalah siasat dosen dalam mengefektifkan, mengefisienkan serta mengoptimalkan fungsi dan interaksi antara mahasiswa dengan komponen pembelajaran dalam suatu kegiatan peembelajaran untuk mencapa tujuan pembelajaran untuk mencapai tujuan pengajaran. Jumlah sampel yang digunakan adalah sebanyak 43 orang yang merupakan mahasiswa tingkat II EKM A Prodi Manajemen Fakultas Ekonomi Universitas Samudra Tahun Akademik 2016/2017. Metode analisis data dengan menggunakan PTK (Penelitian Tindakan Kelas). Berdasarkan hasil penelitian dan pembahasan dari 43 mahasiswa mata kuliah Statistik Ekonomi terdapat 15 mahasiswa memperoleh nilai diatas 85 (34,8\%) dan 13 mahasiswa mamperoleh nilai diatas 70 (30,2\%). Secara umum nilai rata-rata kelulusan adalah B $(75,81)$ sebesar $65 \%$.
\end{abstract}

Kata Kunci: Metode Inkuiri, Kreativitas, Hasil Belajar

\section{PENDAHULUAN}

Pendidikan merupakan cara agar setiap orang dapat menjadi lebih baik dalam meningkatkan sumber daya manusia, sehingga dapat mengimbangi setiap perkembangan yang terjadi agar tidak tertinggal jauh oleh kemajuan teknologi di zaman modern ini. Pendidikan merupakan tanggung jawab bersama, oleh karena itu perlu adanya kerja sama dari berbagai pihak seperti penentu kebijakan, tidak tergantung kepada satu komponen saja, misalnya pihak kampus, orang tua, dan masyarakat luas. Hal ini perlu disadari bahwa masalah yang dihadapi oleh dunia pendidikan di Indonesia pada saat ini adalah sangat beragam dan kompleks. Salah satunya adalah krisis paradigma berupa kesenjangan dan ketidaksesuaian antara tujuan yang ingin dicapai dan paradigma yang digunakan. Sebagai contoh dari kesenjangan ini, mahasiswa pada setiap jenjang pendidikan dijejali dengan informasi-informasi yang harus dikuasai mahasiswa, sehingga mahasiswa hanya mengetahui pengetahuan jangka pendek, sementara kehidupan di masa depan menuntut pemecahan baru secara inovatif dalam arti mahasiswa dituntut memiliki pengetahuan jangka panjang.

Salah satu faktor terpenting dalam meningkatkan kuantitas dan kualitas pengajaran adalah dosen. Dosen berperan dalam proses belajar-mengajar, yang dapat menciptakan kondisi belajar-mengajar yang efektif, mengembangkan bahan ajar dengan baik, dan meningkatkan kemampuan mahasiswa dalam menyimak mata kuliah yang diajarkan, dan memahami maksud serta tujuan yang ingin dicapai.

Dalam hal ini dosen memegang peranan penting dalam pelaksanaan pembelajaran, sehingga metode yang digunakan banyak menuntut keaktifan dosen dari pada mahasiswa sebagai pembelajar, sehingga mahasiswa kurang aktif dalam proses pembelajaran. Kebanyakan mahasiswa hanya mendengarkan, memperhatikan dan mencatat apa yang diterangkan oleh dosen, sehingga mahasiswa tidak terlatih untuk berpikir mengembangkan ide untuk lebih memantapkan pemahaman tentang suatu konsep. Namun kenyataannya banyak mahasiswa yang mengalami kesulitan dalam memahami dan mengerti tentang mata kuliah yang diajarkan, dan terkadang yang memang acuh tak acuh 
selama proses belajar-mengajar. Masih ada dosen yang terpaku pada satu metode pembelajaran yang digunakan dalam proses belajar mengajar secara terus menerus tanpa pernah memodifikasinya atau menggantikannya dengan metode lain walaupun tujuan pembelajaran yang hendak dicapai berbeda. Hal ini dapat mengakibatkan pencapaian tujuan pembelajaran oleh para mahasiswa tidak optimal dan dapat menimbulkan kejenuhan dalam menerima materi yang diajarkan.

Oleh karena itu, untuk mewujudkan tujuan pembelajaran tersebut, dalam pelaksanaan kegiatan perkulihaan, dosen hendaknya memilih dan menggunakan metode pembelajaran yang melibatkan mahasiswa aktif dalam pembelajar, baik secara mental, fisik maupun sosial.

\section{Konsep Pembelajaran}

Belajar sebagai perubahan perilaku terjadi setelah mahasiswa mengikuti atau mengalami proses belajar mengajar, yaitu berupa hasil dalam bentuk penguasaan kemampuan dalam waktu tertentu. Belajar statistik ekonomi diawali dari hal sederhana kemudian secara bertahap ke yang lebih tinggi. Hasil belajar merupakan ukuran pencapaian dari proses belajar yang ditandai perubahan tingkah laku. Dalam proses belajar statisitik, hasil belajar dapat diamati dari kemampuan mahasiswa dalam menyelesaikan sejumlah evaluasi belajar berupa soal-soal statistik ekonomi. Setelah serangkaian kegiatan belajar mengajar, dosen dituntut untuk mengukur kemampuan mahasiswanya dalam menyerap pelajaran. Tes dilakukan untuk mengetahui sejauh mana materi tersebut dapat dipahami mahasiswa. Setelah diadakan tes didapatlah hasil belajar statistik ekonomi mahasiswa. Hasil belajar baik apabila terus dipertahankan dan ditingkatkan menjadikan mahasiswa berprestasi, ia dianggap memiliki kelebihan yang tidak dimiliki orang lain.

\section{Kreativitas}

Kreativitas bukanlah bakat bawaan seseorang sejak lahir, kreativitas merupakan suatu hal yang dapat dipelajari dan dilakukan siapa saja melalui proses tertentu. Bakat dapat terlihat sedini mungkin sedangkan kreativitas baru terlihat setelah seseorang menghasilkan karya, namun keduanya saling berkaitan. Al-Khalili (2006) berpendapat kreativitas sebagai suatu proses rasionalisasi maksudnya adalah bahwa kreativitas itu merupakan hasil dari pemikiran yang kreatif. Sedangkan bakat kreatif berarti proses rasionalisasi atau ia merupakan produk akal. Dosen harus memahami karakteristik setiap mahasiswa agar proses kegiatan belajar mengajar kondusif dan tujuan awal pembelajaran tercapai.

Mahasiswa kreatif dapat diketahui melalui kepribadian yang ditampilkan sebagai kebiasaan sehingga menjadi ciri-ciri spesifik, yaitu terlihat dari ciri-ciri kemapuan belajar kreatif dan ciri-ciri menyangkut sikap dan perasaan seseorang yang kreatif. Kedua ciri sama penting, karena ditunjang oleh kepribadian yang sesuai. Kreativitas seseorang tidak dapat berkembang secara wajar, misal seorang mahasiswa yang memiliki kemampuan belajar asli, luwes dan lancar, tapi ia malas dan mudah menyerah, maka kemampuan tersebut tidak akan berkembang. Orang kreatif memiliki kepekaan terhadap lingkungan, sehingga berinisiatif dan nampak tidak kehabisan akal. Oleh Karena itu orang kreatif lebih berorientasi kemasa kini dan masa yang akan datang. Kreativitas yang ditunjukkan oleh mahasiswa tengarai oleh perilaku-perilaku yang bagi guru justru dianggap sebagai hal tidak menyenangkan. Misalnya, mahasiswa kreatif memiliki selera humor tinggi, suka bersenda gurai sehingga nampak main-main dalam menerima pelajaran, mahasiswa kreatif tidak suka tradisi, otoritas, dan hal-hal yang rutin, bahkan kadang-kadang terkesan nyentrik dan nyeleneh, tidak bersih dan rapih.

\section{Metode Pembelajaran}

Dalam Kamus Besar Bahasa Indonesia metode adalah cara kerja yang bersistem untuk memudahkan pelaksanaan suatu kegiatan guna mencapai tujuan yang ditentukan. Menurut Sumiati (2009) bahwa metode pembelajaran menekankan pada proses belajar mahasiswa secara aktif dalam upaya memperoleh kemampuan hasil belajar. Metode pembelajaran yang dipilih tentunya 
menghindari upaya penuangan ide kepada mahasiswa sebagaimana terjadi dalam pembelajaran. Penggunaan metode pengajaran yang tepat, khususnya dalam pelajaran statistik pada dasarnya adalah bertujuan untuk memecahkan masalah-masalah yang timbul dalam proses perkuliahan.

Ternyata metode sangatlah penting dalam menghadapi persoalan atau permasalahan. Terhadap mahasiswa, pemecahan masalah sangatlah penting dalam keberhasilan perkuliahan. Semakin banyak mahasiswa dapat memecahkan suatu persoalan, maka daya pikirnya juga akan semakin baik. Agar mahasiswa dapat dengan cepat dan tepat dalam memecahkan suatu persoalan, maka perlu adanya suatu metode. Setelah kita mengetahui teori yang disebutkan di atas, maka dapat di simpulkan bahwa yang dimaksud metode pembelajaran statistik adalah suatu cara atau langkahlangkah yang digunakan untuk melaksanakan kegiatan penyampaian materi pembelajaran statistik kepada mahasiswa dengan tujuan agar mahasiswa dapat memecahkan suatu persoalan secara cepat dan tepat. Dick dan Carey dalam Riyanto mengatakan bahwa metode pembelajaran adalah suatu komponen materi atau paket pengajaran dan prosedur yang digunakan untuk membantu mahasiswa dalam mencapai tujuan pengajaran (Riyanto, 2009). Dalam hal ini, metode pengajaran tidak hanya terbatas pada prosedur kegiatan, melainkan juga seluruh komponen materi dan pola pengajaran itu sendiri. Rianto menjelaskan bahwa metode pembelajaran adalah siasat dosen dalam mengefektifkan, mengefisienkan serta mengoptimalkan fungsi dan interaksi antara mahasiswa dengan komponen pembelajaran dalam suatu kegiatan peembelajaran untuk mencapai tujuan pembelajaran untuk mencapai tujuan pengajaran (Riyanto, 2009). Metode pembelajaran adalah rencana dan cara-cara yang digunakan pada suatu pembelajaran untuk membantu mahasiswa agar segala tujuan pengajaran dapat dicapai secara efektif. Metode pembelajaran yang dipilih oleh pengajar akan berpengaruh besar terhadap tingkat ketercapaian tujuan pembelajaran (hasil belajar).

\section{Metode Inkuiri}

Pengertian Inkuiri dari National Sciences Education Standards-NSES (Sitiatava, 2013) mendifinisikan arti Inkuiri adalah sebagai aktivitas beraneka ragam yang meliputi observasi, membuat pertanyaan dan memeriksa buku-buku atau sumber informasi lain untuk melihat sesuatu yang telah diketahui, merencanakan investigasi, memeriksa kembali sesuatu yang sudah diketahui menurut bukti eksperimen, menggunakan alat untuk mengumpulkan, menganalisis, dan menginterpretasikan data, mengajukan jawaban, penjelasan, dan prediksi serta mengomunikasikan hasil. Ausmsi-asumsi yang mendasari model inkuiri adalah: Mahasiswa harus mampu mewujudkan yang baru dalam mencapai hasil belajar. Secara tradisional kreativitas dibatasi sebagai mewujudkan sesuatu yang baru dalam kenyataanya. Sesuatu yang baru itu mungkin berupa perbuatan atau tingkah laku suatu bangunan misalnya sebuah gedung, hasil-hasil kesustraan, dan lain-lain.

Metode Inkuiri menurut Suryosubroto (2002) adalah perluasan proses discovery yang digunakan lebih mendalam. Artinya proses Inkuiri mengandung proses-proses mental yang lebih tinggi tingkatannya, misalnya merumuskan problema, merancang eksperimen, melakukan eksperimen, mengumpulkan dan menganalisis data, menarik kesimpulan, dan sebagainya. Hanafiah (2009) menjelaskan bahwa proses Inkuiri menuntut dosen bertindak sebagai fasilitator, narasumber dan penyuluh kelompok. Para mahasiswa didorong untuk mencari pengetahuan sendiri, bukan dijejali dengan pengetahuan. Metode Inkuiri yang diintegrasikan dalam pembelajaran kelompok dapat dilakukan dengan langkah-langkah berikut:

1. Membentuk kelompok-kelompok Inkuiri. Masing-masing kelompok dibentuk berdasarkan rentang intelektual dan keterampilan sosial

2. Memperkenalkan topik-topik Inkuiri kepada semua kelompok. Tiap kelompok diharapkan memahami dan berminat mempelajarinya. 
3. Membentuk posisi tentang kebijakan yang bertalian dengan topik, yakni pertanyaan apa yang harus dikerjakan. Mungkin terdapat satu atau lebih solusi yang diusulkan

4. Merumuskan semua istilah yang terkandung di dalam proposi kebijakan

5. Menyelidiki validitas logis dan konsisten internal pada proporsi dan unsur- unsur penunjangnya

6. Mengumpulkan evidensi (bukti) untuk menunjang unsur proporsi

7. Menganalisis solusi yang diusulkan dan pencari posisi kelompok.

8. Menilai proses kelompok.

\section{METODE PENELITIAN}

Populasi dan Sampel

Dalam penelitian ini populasi/sampel yang dimaksud adalah Mahasiswa Tingkat II EKM A Prodi Manajemen Fakultas Ekonomi Universitas Samudra Tahun Akademik
2016/2017. Jumlah sampel yang digunakan adalah sebanyak 43 orang.

Sesuai dengan prinsip kerja dalam penelitian tindakan kelas maka langkahlangkah kerja dalam penelitiain adalah sebagai berikut:

1. Membuat skenario pembelajaran

2. Mempersiapkan fasilitas dan sarana pendukung

3. Mempersiapkan cara menerapkan dan menganalisis data

4. Melakukan analisis data

5. Melakukan refleksi terhadap pembelajaran yang dilakukan dalam rangka pencapaian tujuan akhir.

6. Memperbaiki skenario pembelajaran berdasarkan hasil refleksi

7. Pelaksanaan tindakan kelas (siklus II), dalam hal ini dilakukan penekanan keadaan kelas pada kelas yang berbeda.

8. Menganalisis data (siklus II)

9. Melakukan refleksi (siklus II)

Tabel 1. Tahapan Pembelajaran Inkuiri

\section{Tahapan Perilaku Dosen}

Tahap -1 Dosen membimbing mahasiswa mengidentifikasi masalah dan masalah Menyajikan atau dituliskan, membagi mahasiswa dalam kelompok.

pertanyaan atau

masalah

\begin{tabular}{cl}
\hline Tahap-2 & $\begin{array}{l}\text { Dosen memberikan kesempatan pada mahasiswa untuk berpendapat dalam } \\
\text { membentuk hipotesis dan membimbing mahasiswa dalam menemukan } \\
\text { hipotesis yang relevan dengan permasalahan dan memprioritaskan hipotesis } \\
\text { mana yang menjadi prioritas penyelidikkan. }\end{array}$ \\
\hline $\begin{array}{c}\text { Tahap-3 } \\
\text { Merancang percobaan }\end{array}$ & $\begin{array}{l}\text { Dosen memberi kesempatan pada mahasiswa untuk menentukan langkah- } \\
\text { langkah yang sesuai dengan hipotesis yang akan dilakukan serta membimbing } \\
\text { mahasiswa mengurutkan langkah-langkah percobaan. }\end{array}$ \\
\hline $\begin{array}{c}\text { Tahap -4 } \\
\text { Melakukan percobaan } \\
\text { untuk memperoleh } \\
\text { informasi }\end{array}$ & Dosen membimbing mahasiswa mendapatkan informasi melalui percobaan. \\
\hline $\begin{array}{c}\text { Tahap-5 } \\
\text { Mengumpulkan dan } \\
\text { menganalisis data }\end{array}$ & $\begin{array}{l}\text { Dosen memberi kesempatan pada tiap kelompok untuk menyampaikan hasil } \\
\text { pengolahan data yang terkumpul. }\end{array}$ \\
\hline $\begin{array}{c}\text { Tahap-6 } \\
\text { Membuat kesimpulan }\end{array}$ & Dosen membimbing mahasiswa dalam membuat kesimpulan. \\
\hline
\end{tabular}


Tabel 2. Skor Mahasiswa dalam Mata Kuliah Statistik Ekonomi

\begin{tabular}{|c|c|c|c|}
\hline No & Skor & Kriteria Nilai Huruf & Kriteria Nilai Mutu \\
\hline 1. & 45 & $\mathrm{D}$ & Kurang \\
\hline 2. & 45 & $\mathrm{D}$ & Kurang \\
\hline 3. & 60 & $\mathrm{C}$ & Cukup \\
\hline 4. & 45 & $\mathrm{D}$ & Kurang \\
\hline 5. & 55 & $\mathrm{C}$ & Cukup \\
\hline 6. & 65 & $\mathrm{C}$ & Cukup \\
\hline 7. & 95 & $\mathrm{~A}$ & Amat Baik \\
\hline 8. & 50 & $\mathrm{C}$ & Cukup \\
\hline 9. & 85 & A & Amat Baik \\
\hline 10. & 45 & $\mathrm{D}$ & Kurang \\
\hline 11. & 55 & $\mathrm{C}$ & Cukup \\
\hline 12. & 45 & $\mathrm{D}$ & Kurang \\
\hline 13. & 45 & $\mathrm{D}$ & Kurang \\
\hline 14. & 75 & B & Baik \\
\hline 15. & 40 & $\mathrm{D}$ & Kurang \\
\hline 16. & 45 & $\mathrm{D}$ & Kurang \\
\hline 17. & 55 & $\mathrm{C}$ & Cukup \\
\hline 18. & 75 & $\mathrm{~B}$ & Baik \\
\hline 19. & 90 & $\mathrm{~A}$ & Amat Baik \\
\hline 20. & 45 & $\mathrm{D}$ & Kurang \\
\hline 21. & 50 & $\mathrm{D}$ & Kurang \\
\hline 22. & 95 & A & Amat Baik \\
\hline 23. & 95 & $\mathrm{~A}$ & Amat Baik \\
\hline 24. & 65 & $\mathrm{C}$ & Cukup \\
\hline 25. & 60 & $\mathrm{C}$ & Cukup \\
\hline 26. & 50 & $\mathrm{C}$ & Cukup \\
\hline 27. & 75 & $\mathrm{~B}$ & Baik \\
\hline 28. & 95 & $\mathrm{~A}$ & Amat Baik \\
\hline 29. & 70 & B & Baik \\
\hline 30. & 45 & $\mathrm{D}$ & Kurang \\
\hline 31. & 90 & $\mathrm{~A}$ & Amat Baik \\
\hline 32. & 90 & $\mathrm{~A}$ & Amat Baik \\
\hline 33. & 70 & $\mathrm{~B}$ & Baik \\
\hline 34. & 45 & $\mathrm{D}$ & Kurang \\
\hline 35. & 35 & $\mathrm{E}$ & Sangat Kurang \\
\hline 36. & 20 & $\mathrm{E}$ & Sangat Kurang \\
\hline 37. & 50 & $\mathrm{D}$ & Kurang \\
\hline 38. & 45 & $\mathrm{D}$ & Kurang \\
\hline 39. & 90 & $\mathrm{~A}$ & Amat Baik \\
\hline 40. & 75 & $\mathrm{~B}$ & Baik \\
\hline 41. & 35 & $E$ & Sangat Kurang \\
\hline 42. & 90 & $\mathrm{~A}$ & Amat Baik \\
\hline 43. & 90 & $\mathrm{~A}$ & Amat Baik \\
\hline & Jumlah & 2685 & \\
\hline & Rata-rata & 62,44 & Cukup \\
\hline
\end{tabular}

Sumber: Hasil Penelitian, 2017 


\section{Metode Pengumpulan Data}

Data yang diperoleh dalam penelitian ini terdiri dari tiga jenis, yaitu: (1) Data hasil belajar dengan memberikan test kepada mahasiswa; (2) Data situasi pembelajaran dalam bentuk observasi; (3) Hasil interview mahasiswa.

\section{Metode Analisis Data}

Penelitian Tindakan Kelas (PTK) yang terdiri dari empat tahapan, yaitu perencanaan, pelaksanaan tindakan, observasi yang memuat pencatatan, dan interview.

\section{HASIL PENELITIAN}

Indikator-indikator keberhasilan dalam pembelajaran dengan menggunakan pembelajaran metode Inkuiri ditunjukkan dengan data yang diperoleh dalam penelitian sebagai berikut:

\section{Siklus I}

\section{Hasil Belajar Mahasiswa}

Daya serap mahasiswa setelah melaksanakan siklus I, diperoleh skor mahasiswa dalam dalam mata kuliah Statistik Ekonomi sebagai berikut:

Pada akhir siklus I, diperoleh informasi daya serap mahasiswa dari hasil quiz maupun penugasan penugasan oleh dosen pada mata kuliah Statistik Ekonomi dapat uraikan bahwa mahasiswa yang memperoleh nilai minimal 20 terdapat 1 orang $(2,3 \%)$, nilai 35 terdapat 2 orang $(4,7 \%)$, nilai 40 terdapat 1 orang $(2,3 \%)$, nilai 45 terdapat 11 orang $(25,6 \%)$, nilai 50 terdapat 4 orang $(9,3 \%)$, nilai 55 terdapat 3 orang (7\%), nilai 60 terdapat 2 orang $(4,7 \%)$, nilai 65 terdapat 2 orang $(4,7 \%)$, nilai 70 terdapat 2 orang $(4,7 \%)$, nilai 75 terdapat 4 orang $(9,3 \%)$, nilai 85 terdapat 1 orang $(2,3 \%)$, nilai 90 terdapat 6 orang $(14,3 \%)$, dan nilai 95 terdapat 3 orang $(9,3 \%)$. Sedangkan secara keseluruhan bahwa rata-rata keberhasilan mahasiswa dalam penguasaan materi Statistik Ekonomi adalah 62,44 (C). Ini menunjukkan hasil belajar mata kuliah Statistik Ekonomi perlu ditingkatkan terutama bagi mahasiswa yang memperoleh nilai di atas 55-69 (C) dan mahasiswa yang memperoleh nilai kurang dari 55-69 (D). Selain itu mahasiswa yang memperoleh nilai B (baik) dan Nilai A (Amat Baik) perlu di pertahankan, dan apabila memungkinkan perlu ditingkatkan lagi. Bila dilihat dari kreativitas mahasiswa dalam penyelesaian tugas-tugas juga perlu ditingkatkan lagi. Dengan mengetahui data hasil belajar mahasiswa tersebut di atas, maka peneliti merasa perlu untuk melakukan pelaksaan metode pembelajaran Inkuiri pada siklus II untuk meningkatkan hasil belajar dan kretivitas belajar mahasiswa pada mata kuliah Statistik Pendidikan.

Gambaran Kondisi kelas pada siklus I ketika dosen melaksanakan kegiatan pembelajaran mata kuliah Statistik Ekonomi:

\section{Tahap I: Saat Dosen Menyampaikan Tujuan dan Kretivitas Mahasiswa}

Ketika dosen menyampaikan tujuan dan kretivitas mahasiswa, keadaan kelas kurang kondusif dan kreativitas mahasiswa kurang maksimal, dalam hal ini mahasiswa kurang serius terhadap penjelasan dosen. Kemudian dosen memberikan penjelasan beberapa materi pokok perkuliahan dengan memberikan penekanan khusus pada pokokpokok bahasan yang sesuai dengan tujuan, dilanjutkan dengan pemberian masalah yang seharusnya dapat diselesaikan mahasiswa, baik secara kelompok maupun individu. Pada tahap I ini pembelajaran lebih banyak menggunakan metode pembelajaran Inkuiri, disini tampak bahwa mahasiswa kurang aktif. Sebab sebagian besar dari mereka banyak yang belum aktif menjawab pertanyaan yang diberikan oleh dosen. Beberapa mahasiswa yang telah menyiapkan materi dari rumah lebih antusias dan puas dengan motode pembelajaran Inkuiri. Kendalanya, penguasaan kelas belum maksimal dikarenakan faktor mahasiswa yang belum terbiasa dengan metode pembelajaran Inkuiri. Usaha untuk mengatasi hal tersebut, dosen harus lebih terampil dalam pengelolaan kelas dan dosen harus siap terhadap materi pokok dan materi penunjang yang sesuai dengan tujuan pembelajan yang disajikan pada saat itu. 


\section{Tahap II: Kondisi Kelas pada Saat Menyajikan Masalah}

Saat dosen menyajikan masalah, terlihat mahasiswa lebih serius dan memperhatikan, keadaan kelas semakin kondusif, dosen menyajikan permasalahan secara jelas kepada mahasiswa untuk kemudian diselesaikan oleh mahasiswa. Pada fase ini, mahasiswa juga diberikan pengarahan singkat tentang penggunaan media yang sudah tertulis pada Lembar Kerja Mahasiswa yang telah diberikan kepada mahasiswa. Tujuannya adalah untuk membantu para mahasiswa untuk menjadi pembaca, pengamat sekaligus pekerja dan membantu mahasiswa untuk memiliki tanggung jawab tanpa tergantung penuh pada dosen. Kendala, kretivitas kepada mahasiswa masih perlu diperbaiki, agar mahasiswa lebih giat dalam metode pembelajaran Inkuiri. Usaha untuk mengatasi hal tersebut, kretivitas harus lebih ditingkatkan mengingat mahasiswa baru mengalami metode pembelajaran Inkuiri.

\section{Tahap III: Proses Identifikasi dan Perumusan Masalah Pembelajaran}

Pada saat mengorganisasikan mahasiswa ke dalam bentuk kelompok, keadaan kelas mulai sedikit gaduh. Hal ini disebabkan peralihan tempat duduk antar mahasiswa. Akan tetapi hal ini tidak terjadi lagi pada tahap III. Setelah menyajikan masalah mahasiswa dihadapkan untuk merasakan dan mengidentifikasikan masalah yang telah diberikan. Kemudian mereka dituntut untuk menganalisis serta merumuskan masalah yang telah diberikan. Hal ini merupakan kelanjutan dari fase II dimana mahasiswa telah merumuskan bagaimana sebenarnya cara untuk menyelesaikan permasalahan tersebut. Kendalanya, ketidaksiapan mahasiswa untuk menganalisis soal dengan cepat dalam pembelajaran ini. Akibatnya permasalahan tidak dapat dijawab dengan cepat. Usaha untuk mengatasi hal tersebut, membiasakan mahasiswa memberikan kajian secara cepat melalui bahan bacaan yang disediakan.

\section{Tahap IV: Pembimbingan Individu dan Kelompok \\ Saat \\ dosen \\ membimbing}

individu/kelompok untuk bekerja dan belajar, dosen harus selalu siap membantu mahasiswa sewaktu-waktu. Akan tetapi dalam hal ini dosen tidak ikut campur terlalu banyak karena dapat menganggu mahasiswa. Jadi mahasiswa lebih ditekankan untuk berkretivitas sendiri. Mahasiswa juga diberikan kesempatan untuk bekerja dengan inisiatifnya sendiri. Tujuannya agar terbentuk kerjasama dalam kelompok, mengingat banyaknya jumlah kelompok. Dalam hal ini dosen harus mengingatkan kepada mahasiswa mengenai waktu pelaksanaan, agar pembelajaran tersebut dapat berjalan secara optimal. Kendalanya, mahasiswa masih belum menguasai metode pembelajaran Inkuiri, sehingga mereka masih sulit untuk memberikan pertanyaan. Usaha untuk mengatasi hal tersebut, dalam hal ini dosen harus lebih teliti yaitu dengan cara memberikan kesempatan bagi tiap kelompok untuk mengajukan satu pertanyaan.

\section{Tahap V: Evaluasi dan Membimbing Penyelesaian Masalah}

Sebelum evaluasi berlangsung, dosen harus mengkondisikan kelas terlebih dahulu. Kemudian setiap kelompok diberikan kesempatan untuk mempresentasikan hasil kerjanya didepan kelas, dengan dosen sebagai moderator sekaligus narasumber. Saat presentasi berlangsung tampak semua mahasiswa antusias memperhatikan rekanrekannya yang sedang presentasi. Setelah presentasi dosen sebagai moderator membuka seksi/fase tanya jawab sebanyak tiga pertanyaan dan untuk setiap kelompok yang mewakili hanya boleh memberikan satu pertanyaan. Setelah pertanyaan pertanyaan terkumpul mahasiswa yang presentasi diberikan kesempatan untuk menjawab dan menyimpulkan hasil jawaban. Setelah semua pertanyaan terjawab dan penanya merasa puas, berakhirlah presentasi dari kelompok tersebut dan kemudian dosen memberihan kesimpulan. Berdasarkan berbagai kendala pada siklus I di atas, maka akan diperbaiki pada siklus berikutnya, yaitu siklus II. 
Tabel 3. Skor Mahasiswa dalam Mata Kuliah Statistik Ekonomi

\begin{tabular}{|c|c|c|c|}
\hline No & Skor & Kriteria Nilai Huruf & Kriteria Nilai Mutu \\
\hline 1. & 70 & $\mathrm{~B}$ & Baik \\
\hline 2. & 70 & B & Baik \\
\hline 3. & 60 & $\mathrm{C}$ & Cukup \\
\hline 4. & 70 & $\mathrm{~B}$ & Baik \\
\hline 5. & 60 & $\mathrm{C}$ & Cukup \\
\hline 6. & 55 & $\mathrm{C}$ & Cukup \\
\hline 7. & 62,5 & $\mathrm{C}$ & Cukup \\
\hline 8. & 100 & $\mathrm{~A}$ & Amat Baik \\
\hline 9. & 65 & $\mathrm{C}$ & Cukup \\
\hline 10. & 70 & B & Baik \\
\hline 11. & 60 & $\mathrm{C}$ & Cukup \\
\hline 12. & 70 & $\mathrm{~B}$ & Baik \\
\hline 13. & 70 & $\mathrm{~B}$ & Baik \\
\hline 14. & 100 & $\mathrm{~A}$ & Amat Baik \\
\hline 15. & 70 & $\mathrm{~B}$ & Baik \\
\hline 16. & 70 & B & Baik \\
\hline 17. & 60 & $\mathrm{C}$ & Cukup \\
\hline 18. & 100 & $\mathrm{~A}$ & Amat Baik \\
\hline 19. & 100 & A & Amat Baik \\
\hline 20. & 100 & A & Amat Baik \\
\hline 21. & 100 & $\mathrm{~A}$ & Amat Baik \\
\hline 22. & 40 & $\mathrm{D}$ & Kurang \\
\hline 23. & 100 & $\mathrm{~A}$ & Amat Baik \\
\hline 24. & 100 & A & Amat Baik \\
\hline 25. & 60 & $\mathrm{C}$ & Cukup \\
\hline 26. & 100 & A & Amat Baik \\
\hline 27. & 50 & $\mathrm{C}$ & Cukup \\
\hline 28. & 70 & $\mathrm{~B}$ & Baik \\
\hline 29. & 100 & $\mathrm{~A}$ & Amat Baik \\
\hline 30. & 70 & B & Baik \\
\hline 31. & 100 & $\mathrm{~A}$ & Amat Baik \\
\hline 32. & 100 & $\mathrm{~A}$ & Amat Baik \\
\hline 33. & 50 & $\mathrm{C}$ & Cukup \\
\hline 34. & 70 & $\mathrm{~B}$ & Baik \\
\hline 35. & 92,5 & $\mathrm{~A}$ & Amat Baik \\
\hline 36. & 85 & $\mathrm{~A}$ & Amat Baik \\
\hline 37. & 62,5 & $\mathrm{C}$ & Cukup \\
\hline 38. & 65 & $\mathrm{C}$ & Cukup \\
\hline 39. & 67,5 & $\mathrm{C}$ & Cukup \\
\hline 40. & 100 & $\mathrm{~A}$ & Amat Baik \\
\hline 41. & 75 & $\mathrm{~B}$ & Baik \\
\hline 42. & 50 & $\mathrm{D}$ & Kurang \\
\hline 43. & 70 & $\mathrm{~B}$ & Baik \\
\hline & Jumlah & 3260 & \\
\hline & Rata-rata & 75,81 & Baik \\
\hline
\end{tabular}

Sumber: Hasil Penelitian, 2017 


\section{Siklus II}

\section{Hasil Belajar Mahasiswa}

Daya serap mahasiswa setelah melaksanakan siklus I, diperoleh skor mahasiswa dalam mata kuliah Statistik Pendidikan sebagai berikut:

Pada akhir siklus II, diperoleh informasi daya serap mahasiswa yang diperoleh dari hasil quiz maupun penugasan oleh dosen pada mata kuliah Statistik Ekonomi dapat uraikan bahwa mahasiswa yang memperoleh nilai minimal 40 terdapat 1 orang $(2,3 \%)$, nilai 50 terdapat 3 orang $(7 \%)$, nilai 55 terdapat 1 orang $(2,3 \%)$, nilai 60 terdapat 5 orang $(11,6 \%)$, nilai 62,5 terdapat 2 orang $(4,7 \%)$, nilai 67,5 terdapat 2 orang $(4,7 \%)$, nilai 70 terdapat 12 orang $(27,9 \%)$, nilai 75 terdapat 1 orang $(2,3 \%)$, nilai 85 terdapat 1 orang $(2,3 \%)$, nilai 92,5 terdapat 1 orang $(2,3 \%)$, dan nilai 100 terdapat 13 orang $(30,2 \%)$. Sedangkan secara keseluruhan bahwa ratarata keberhasilan mahasiswa dalam penguasaan materi kuliah Statistik Ekonomi adalah B $(75,81)$. Ini menunjukkan bahwa hasil belajar mata kuliah Statistik Ekonomi perlu pertahankan pada pembelajaran tahun yang akan datang. Bila dilihat dari kretivitas mahasiswa dalam mengerjakan tugas-tugas juga dapat dikategorikan baik, apalagi apabila dibandingkan dengan tugas-tugas yang diberikan pada siklus sebelumnya. Dengan data tersebut di atas maka peneliti merasa puas perlu untuk melakukan pelaksanaan metode pembelajaran Inkuiri.

\section{KESIMPULAN}

Berdasarkan hasil penelitian dan pembahasan sampai dengan akhir siklus II, diperoleh kesimpulan sebagai berikut:

1. Dari 43 mahasiswa mata kuliah Statistik Ekonomi terdapat 15 mahasiswa

memperoleh nilai diatas $85(34,8 \%)$ dan 13 mahasiswa mamperoleh nilai diatas 70 $(30,2 \%)$. Secara umum nilai rata-rata kelulusan adalah B $(75,81)$ sebesar $65 \%$.

2. Hingga akhir siklus II, aktivitas belajar mahasiswa di dalam kelas dapat dikatakan Efektif dengan motivasi belajar tinggi. Mahasiswa sudah mempunyai keberanian berpendapat dan mampu mengaplikasikan rumus-rumus statistika dengan benar sesuai dengan variabel-variabel/pokok permasalahan yang dianalisisnya.

\section{DAFTAR PUSTAKA}

Al-Khalili, Amal Abdussalam.2006. Mengembangkan Kreativitas Anak. Jakarta: Pustaka Al Kautsar.

Agung, Iskandar. 2010. Meningkatkan Kreativitas Belajar bagi Guru. Jakarta: Bestari Buana Murni.

Hanafiah, Nanang. 2012. Konsep Strategi Pembelajaran. Bandung: Refika.

Aditama. Kesuma, Dharma. 2010. Contextual Teaching and Learning. Yogyakarta: Rahayasa.

Mulyasa. 2003. Strategi Pembelajaran. Bandung: Remaja Rosdakarya.

Sitiatava, Rizema Putra. 2013. Desain Belajar Mengajar Kreatif Berbasis Sains. Yogyakarta: Diva Press.

Suryosubroto. 2002. Proses Belajar Mengajar di Sekolah. Jakarta: Rineka Cipta.

Riyanto, Yatim. 2009. Paradigma Baru Pembelajaran. Jakarta: Kencana.

Roestiyah. 2008. Strategi Belajar Mengajar. Jakarta: Rineka Cipta.

Uno, Hamzah dan Masri Kuadrat. 2009. Mengelola Kecerdasan dalam Pembelajaran. Jakarta: Bumi Aksara. 